\title{
PEMBERDAYAAN MASYARAKAT BERBASIS POTENSI LOKAL MELALUI PENINGKATAN PRODUKTIVITAS LEBAH MADU TRIGONA BATU KATAK
}

https://doi.org/10.33024/jkpm.v4i6.4354

\author{
Yayuk Yuliana $^{1^{*}}$, Minda Sari Lubis ${ }^{2}$, Vera Kristiana ${ }^{3}$ \\ 1,2,3Universitas Muslim Nusantara Al Washliyah
}

Email Korespondensi:yayukyuliana@umnaw.ac.id

\begin{abstract}
ABSTRAK
Budidaya lebah madu lebih banyak dilakukan di bawah daerah penyangga hutan. Kelompok Budidaya Trigona Batu Katak yang dijalankan Bapak Kelengi Sitepu merupakan penjual sekaligus peternak di dusun Batu Katak, Desa Batu Jong-Jong. Bapak Kelengi Sitepu memproduksi madu unggulanya yaitu Trigona Batu Katak. Proses pengolahan Madu ini dimulai ketika lebah madu siap panen. Kemudian dilakukan pemerasan sari madu menggunakan alat sederhana, dan ditampung ke dalam jerigen untuk dikemas. Proses pemerasan pengemasan madu dilakukan di rumah secara manual. Kendala yang dialami oleh pengusaha madu ini adalah pengemasan yang masih sederhana belum menggunakan label dan botol yang menarik sehingga sulit untuk menembus toko. Berdasarkan permasalahan mitra tersebut diatas, kami akan memberikan solusi dengan metode pelaksanaan yaitu pendampingan dan penerapan pengemasan dan label kemasan. Hasil yang dicapai setelah pelaksanaan kegiatan tersebut adalah Dapat membuat kemasan botol madu lebih menarik sehingga memiliki daya saing dipasaran salah satunya pada saat pandemic covid 19 ini,pihak Kantor Balai Besar Taman Nasional Gunung sudah memesan dan mengkonsumsi Madu Trigona Batu Katak.
\end{abstract}

Kata Kunci: Kemasan, Madu, Lebah, Budidaya

\section{ABSTRACT}

The cultivation of honey bees is mostly carried out in the buffer zones. The Trigona Batu Katak Cultivation Group, which is run by Mr. Kelengi Sitepu, is a seller as well as a breeder in Batu Katak hamlet, Batu Jong-Jong Village. Mr. Kelengi Sitepu produces his superior honey, namely Trigona Batu Katak. This honey processing process begins when the honey bees are ready to harvest. Then the honey juice is squeezed using a simple tool, and it is put into a jerry can for packaging. The process of squeezing the honey packaging is done at home manually. The constraints that serve honey entrepreneurs are the simple packaging, not using attractive labels and bottles, making it difficult to get through to the collection. Based on the partners' problems mentioned above, we will provide a solution with the implementation method, namely assistance and application of packaging and packaging labels. The 
results achieved after the implementation of this activity were being able to make honey bottle packaging more attractive so that it had competitiveness in the market, one of which was during the COVID 19 pandemic, the Mount National Park Office had ordered and consumed Trigona Batu Katak Honey.

Keywords: Packaging, Honey, Bees, Cultivation

\section{PENDAHULUAN}

Pemerintah Indonesia mengimbau menerapkan Social Distancing dan melarang masyarakat berkerumun sebagai upaya melawan virus corona atau COVID-19. Covid-19 berdampak ke segala sektor, salah satunya sektor ekonomi. Hal ini dirasakan secara signifikan oleh para pelaku Usaha Mikro Kecil Menengah yang mengalami krisis ekonomi. (https: //nasional.kompas.com). Pada tanggal 2 Maret 2020, Indonesia melaporkan kasus COVID-19 terkonfirmasi sebanyak 2 kasus. (Yurianto, Ahmad, Bambang Wibowo, 2020).

Ditutupnya Ekowisata Batu Katak pada pertengahan Maret tahun 2020 berdampak langsung terhadap pendapatan masyarakat Dusun Batu Katak. Situasi tersebut membuat sebagian pelaku usaha khususnya ekowisata terpaksa tutup dan beralih profesi karena sepinya wisatawan. Masyarakat kembali mengandalkan hasil pertanian berupa karet, sawit, padi, dan palawija. Kondisi ini merupakan peluang bagi Kelengi Sitepu yang telah membudidayakan lebah madu dari jenis Trigona sp. Masyarakat suku Karo pada umumnya menyebut Benben. Kelengi Sitepu dan beberapa warga kemudian membentuk Kelompok Budidaya Trigona Batu Katak pada tahun 2017, hingga saat ini telah menunjukan hasil panen yang bagus.

Budidaya Trigona sp. yang dilakukan Kelompok Budidaya Trigona Batu Katak dusun Batu Katak, Desa Batu Jong-Jong, Kecamatan bahorok Kabupaten langkat. Pengelolaan masih masih tergolong sederhana. Pemberdayaan madu kelulut yang ada di Dusun batu katak, tidak dapat dilepaskan dari modal sosial yang digerakkan oleh masyarakat tersebut. Modal sosial merupakan varian entitas, terdiri dari beberapa struktur sosial yang memfasilitasi tindakan dari para pelakunya, apakah dalam bentuk personal atau korporasi dalam struktur social (Coleman, 2009). Adapun modal sosial terdapat pada proses pemberdayaan masyarakat. Pemberdayaan masayrakat merupakan upaya meningkatkan harkat dan martabat lapisan masayraakat yang dalam kondisi sekarang tidak mampu untuk melepaskan diri dari perangkap kemisikinan dan keterbelakangan. Dengan kata lain memberdayakan adalah memampukan dan memandirikan masyarakat (Rochman, 2017).

Konsep pemberdayaan menekankan pada proses memberikan kemampuan kepada masayrakat dengan memotivasi individu agar mempunyai kemampuan atau keberdayan untuk menentukan pilihannya. Proses pemberdayaan pada masayarakat di dusun Batu Katak terlihat dari bagaimana masayrakat dapat berpikir kreatif untuk mengembangkan kemampuannya dalam memberikan peluang dan inovasi terkait kehidupan ekonomi mereka

Salah satu pilar penting sektor ekonomi nasional yaitu nafas Usaha Mikro Kecil dan Menengah yang membutuhkan perhatian (Hanjani \& Wulaningrum, 2019). Universitas Muslim Nusantara Al washliyah melalui kegiatan Tridarma 
perguruan tinggi melakukan pengabdian kepada masyarakat berbasis penelitian maupun kajian literature yang telah dipublikasikan. Memberikan kontribusi dalam memecahkan permasalahan kelompok budidaya trigona batu katak yang terdampak Covid-19. Saat ini Kelompok Budidaya Trigona Batu Katak mengalami berbagai permasalahan, pengemasan yang kuarang menarik dan penjualan masih terbatas, dengan berhentinya aktivitas kepariwisataan menyebabkan pendapatan menurun, hal ini menjadi ancaman bagi perekonomian masyarakat.

\section{MASALAH}

Pemilihan tempat pengabdian kepada masyarakat didasarkan pada ditutupnya Ekowisata di seluruh kabupaten Langkat pada pertengahan Maret 2020 karena pandemi COVID-19 berdampak langsung terhadap pendapatan masyarakat Dusun Batu Katak . Saat ini kendala yang dihadapi ada yaitu terkait produksi madu yang meliputi pengemasan produk dan yang kedua terkait pemasaran produk. Cara memanen madu juga masih sederhana perlu adanya peralatan yang bisa menjamin kualitas madu.

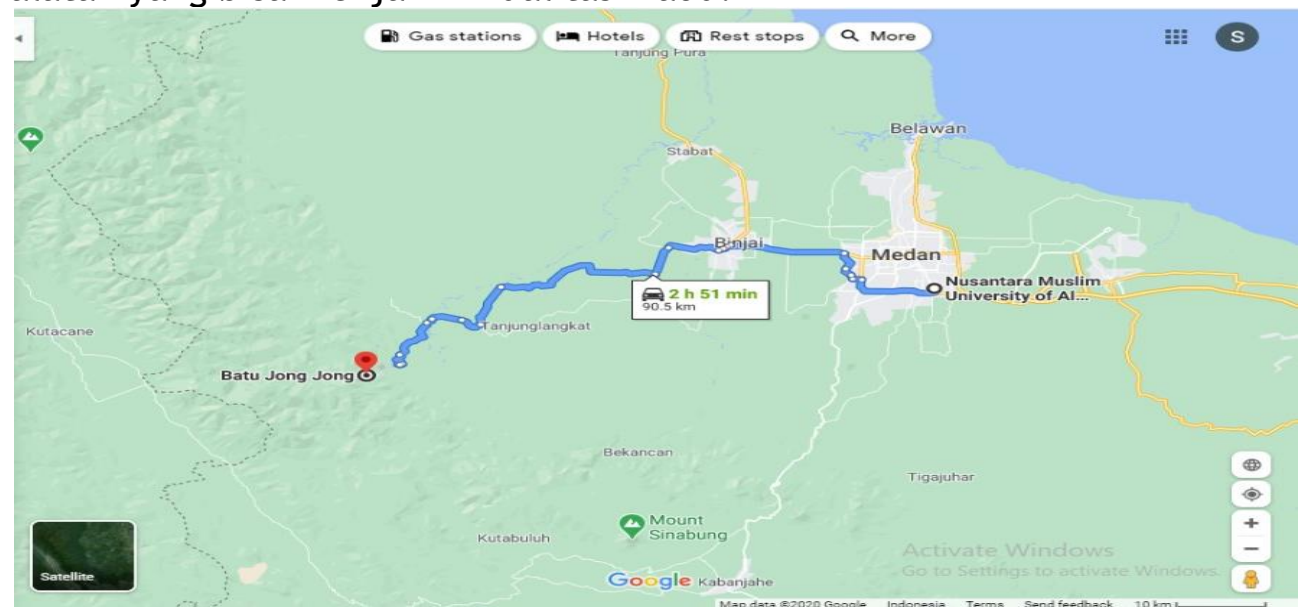

Gambar 2.1. Peta Lokasi Pengabdian Pada Masyarakat

\section{METODE}

a. Tahap Persiapan

Tahap Persiapan, yang dilakukan untuk mempersiapkan berbagai hal sebelum melakukan kegiatan yang meliputi menjalin komunikasi dengan mitra, melakukan studi pendahuluan (Survei Lapangan), mengidentifikasi setiap permasalahan pada mitra dan melakukan penyusunan rencana pemecahan masalah (Problem Solving) Tahap persiapan adalah berkoordinasi dengan tempat pengabdian masyarakat dalam rangka persiapan pelatihan, penyiapan botol pengemas madu sebanyak 500 botol, pengadaan mesin segel, dan penyiapan Madu.

b. Tahap pelaksanaan

Kegiatan ini diawali dengan pemberitahuan kepada mitra dan dilanjutkan dengan Pelatihan Kegiatan PKM ini terdiri diawali dengan survei sistem pengemasan dan pemasaran produk madu hutan secara tradisional dan 
sosialisasi rencana pengemasan dan sistem pemasaran yang akan dilaksanakan dalam kegiatan Pengabdian Kepada Masyarakat.

c. Evaluasi

i. Struktur

Kelompo Budidaya Trogona Batu Katak hadir bersama anggota kelompok hadir - Setting tempat sudah sesuai dengan rencana yang dibuat dan perlengkapan yang dilakukan untuk penyuluhan sudah tersedia dan sudahigunakan sebagaimana mestinya. Penggunaan bahasa yang digunakan sudah komunikatif dalam penyampaiannya menggunakan bahasa Indonesia, memahami materi yang sudah disampaikan tim penngabdian masyarakat dan dapat memfasilitasi audiensi selama berjalannya pelatihan dan diskusi.

ii. Proses

Sesuai dengan jadwal yang telah direncanakan Proses Pelaksanaan kegiatan dimulai Bulan Mei 2021. Proses kegiatan Pengabdian Kepada Masyarakat yang terdiri pemilihan bahan kemasan hingga praktek sistem tiris, pengemasan dan sistem pemasaran. Menurut Rachim dalam (Wahyudi \& Nuddin, 2019), sistem tiris merupakan sistem pemisahan madu dari sarang lebah tanpa melalui proses pemerasan melainkan hanya di tiriskan sehingga dengan sistem ini madu yang diperoleh memiliki kualitas yang lebih baik dan bahan pencemar yang rendah (Sofia et al., 2017)

\section{HASIL DAN PEMBAHASAN}

Peningkatan ketrampilan dalam pelaksanaan PKM dan peningkatan produktivitas Peternak Lebah Madu dilakukan melalui penilaian terhadap pengemasan lebah madu sebelum dan sesudah dilaksanakan kegiatan pendampingan dan penerapan mesin pencetak label kemasan madu (Aini et al., 2019). Madu yang dihasilkan lebah madu ada yang berkualitas baik dan ada yang tidak. (Amstrong, 2010) kualitas produk adalah kemampuan suatu produk untuk melaksanakan fungsinya, meliputi kehandalan, daya tahan, ketepatan, kemudahan operasi, dan perbaikan produk, serta atribut bernilai lainnya. Pemasaran produk Madu Kelompok Budidaya Trigona Batu Katak telah memanfaatkan digital marketing (Y. Yuliana \& Kristiana, 2021). Penggunaan internet, pemasaran terhadap perusahaan, produk, dan pelayanan menjadi proses yang interaktif saat ini (O. Y. Yuliana, 2000 dan ).
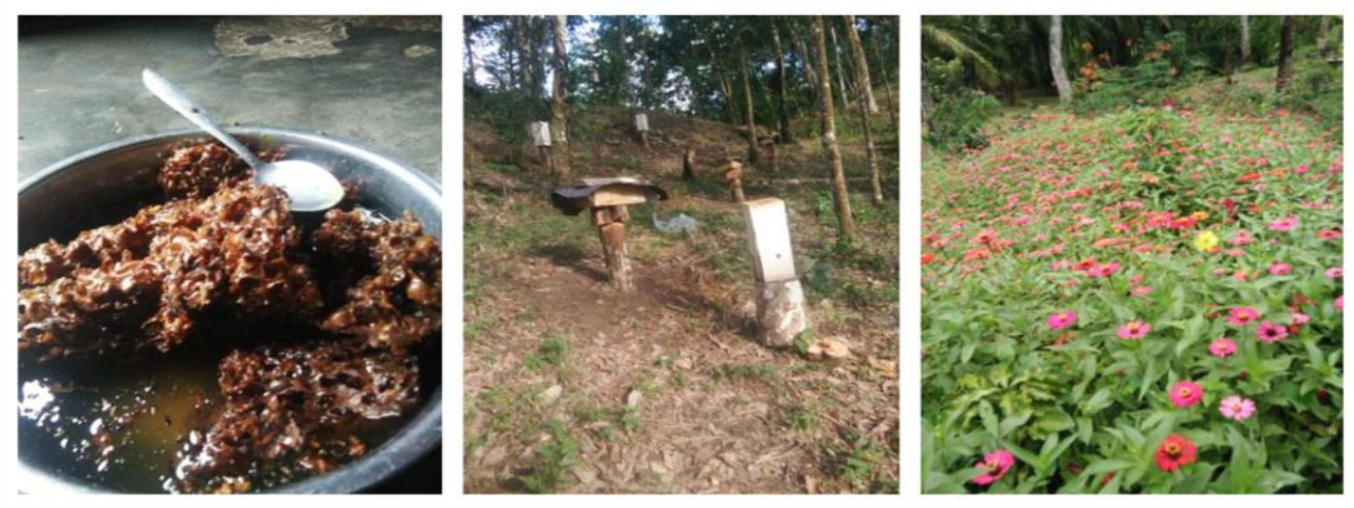

Gambar 2.2. Hasil panen madu secara manual (kiri) dan kondisi lokasi budidaya Trigona sp. (tengah dan kanan) 

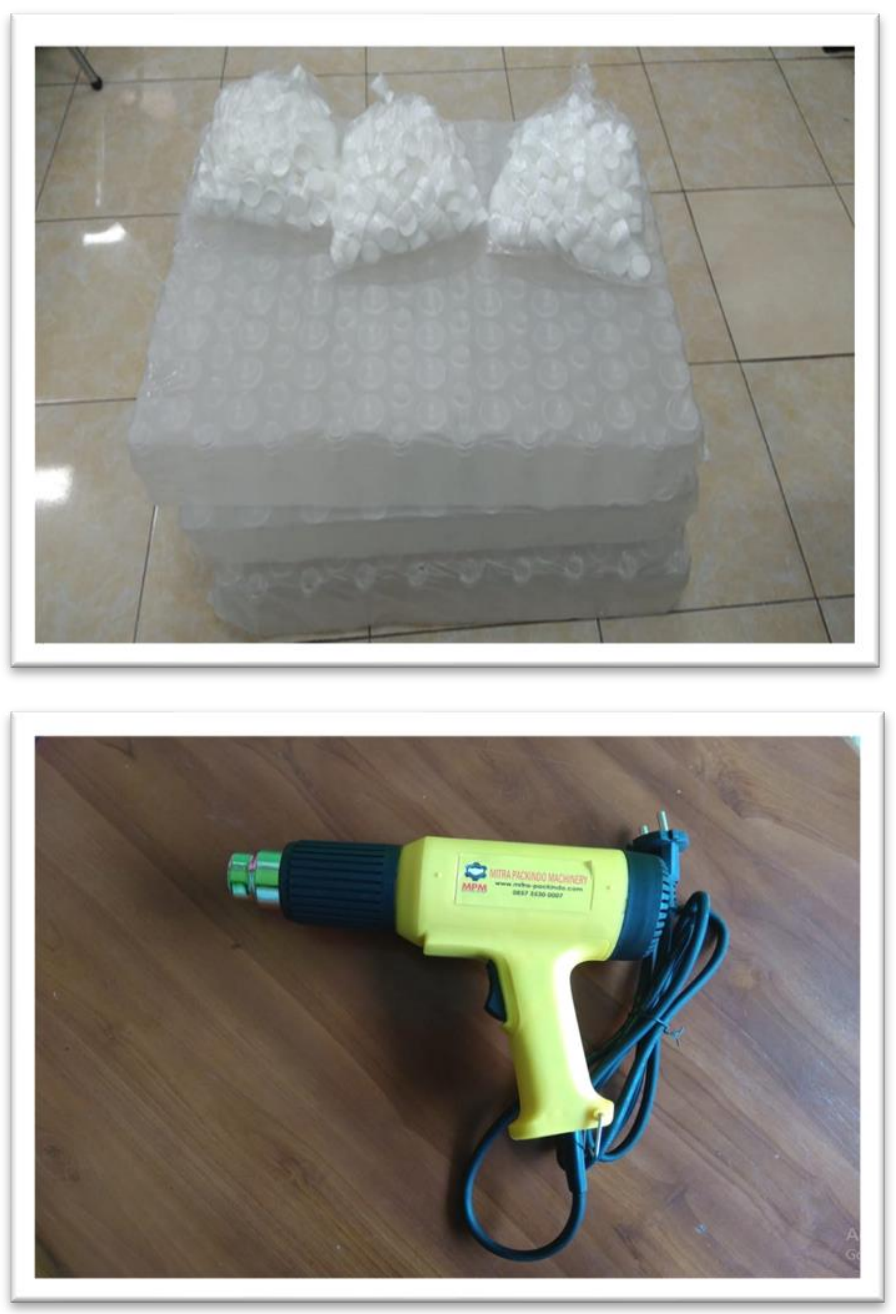

Gambar 2.3 media yang digunakan untuk mengemas madu yang sudah dipanen

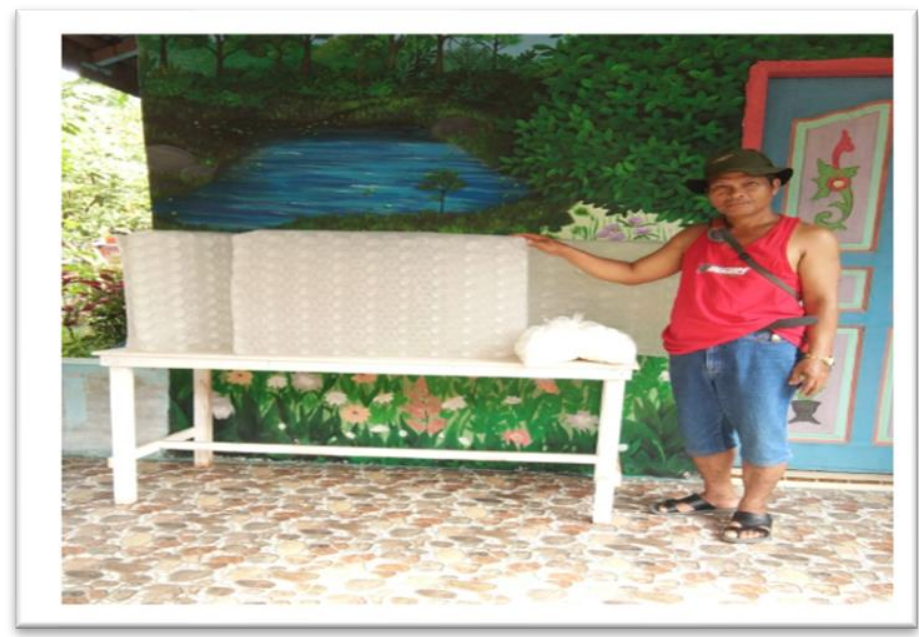

Gambar 2.4 penyerahan botol untuk kemasan madu kepada Bapak Kelengi Sitepu 

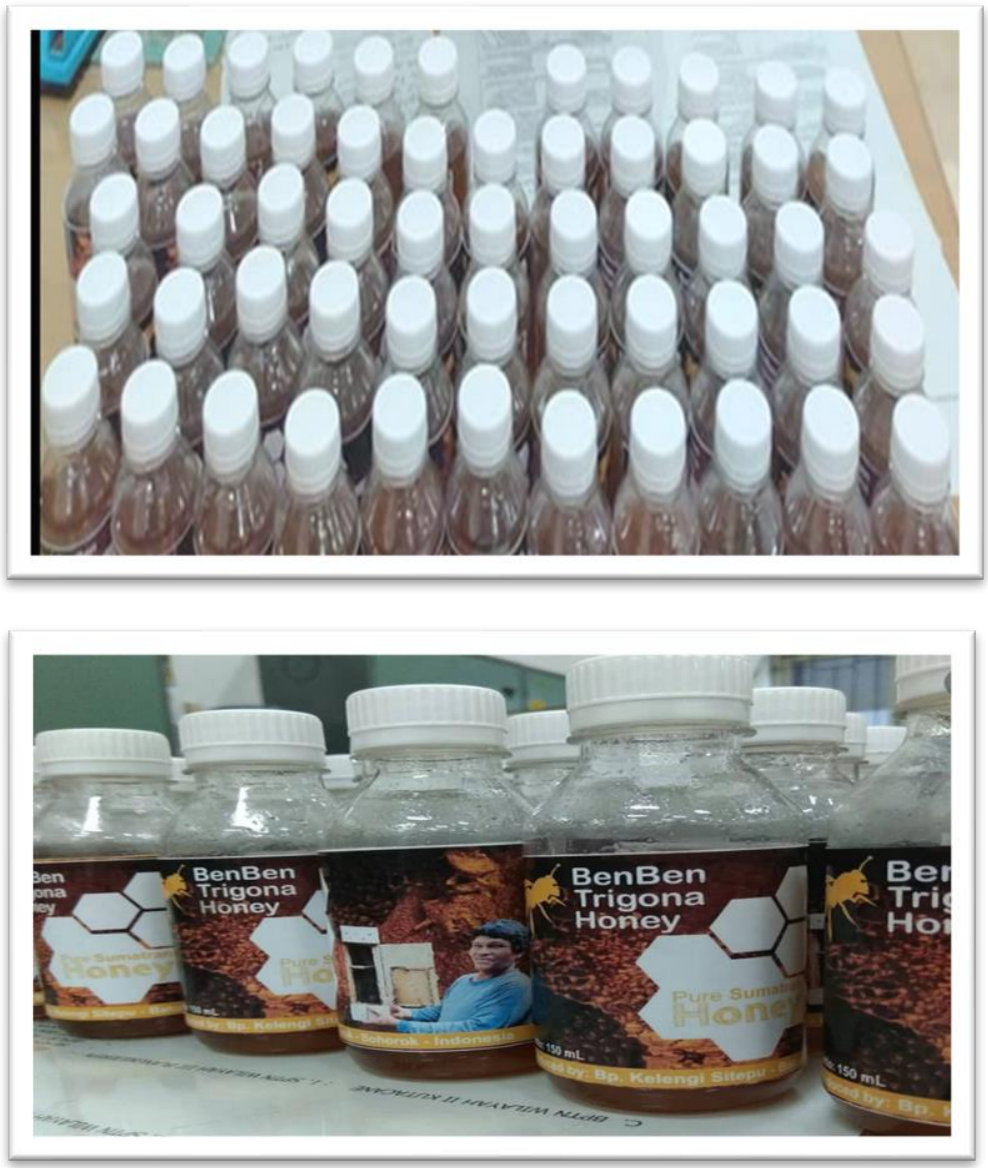

Gambar 2.5 madu yang sudah dikemas dan diberi label siap dipasarkan

\section{KESIMPULAN DAN SARAN}

Berdasarkan hasil pelaksanaan pengabdian pada Kelompok Budidaya Trigona Batu Katak Dusun Batu Katak, dapat disimpulkan bahwa pengemasan dengan menggunakan botol madu dan pelabelan dapat meningkatkan penjualan dengan memanfaatkan digital marketing berupa media social dan Wathsapp. Kemasan botol yang digunakan hasil pelatihan memberikan pengaruh peningkatan pendapatan kelompok Budidaya Trogona Batu Katak. Kegiatan pengabdian bagi masyarakat yang telah dilaksanakan secara keseluruhan baik penyuluhan dan pendampingan, sudah terlaksana dengan baik atas peran serta aktif dari mitra. Hasil dari kegiatan pengabdian masyarakat ini menunjukan bahwa pendampingan yang sudah dilakukan berhasil meningkatkan pengetahuan pengemasan madu untuk peningkatan kualitas produksi dan hasil panen madu yang lebih baik. Untuk selanjutnya supaya tetap memperhatikan quality control pada manajemen usaha. 


\section{DAFTAR PUSTAKA}

Amstrong, K. dan. (2010). Pengertian kualitas produk. Jackson R.S. Weenas Kualitas Produk, Harga, Promosi Dan Kualitas Pelayanan Pengaruhnya Terhadap Keputusan Pembelian Spring Bed Comforta.

Coleman, J. S. (2009). Social capital in the creation of human capital. In Knowledge and Social Capital (pp. 17-42). https://doi.org/10.1086/228943

Hanjani, A., \& Wulaningrum, P. D. (2019). Pemberdayaan dan Strategi Marketing Petani Madu Desa Giri Tengah Kecamatan Borobudur-Magelang. ABDIMAS: Jurnal Pengabdian Masyarakat. https://doi.org/10.35568/abdimas.v2i1.261

Rochman, N. (2017). Model Pengembangan Desa Wisata Berbasis Pemberdayaan Masyarakat. Equilibria Pendidikan: Jurnal Ilmiah Pendidikan Ekonomi. https://doi.org/10.26877/ep.v1i1.1831

Sofia, Zainal, S., \& Roslinda, E. (2017). Pengelolaan madu hutan berbasis kearifan lokal masyarakat di Desa Semalah dan Desa Melemba Kawasan Danau Sentarum, Kabupaten Kapuas Hulu. Jurnal Hutan Lestari, 5(2), 209-218.

Wahyudi, D. P., \& Nuddin, A. (2019). Pengembangan Kelompok Usaha Madu Hutan Di Desa Pappandangan, Polewali Mandar Melalui Program Kemitraan Masyarakat. Jurnal Dedikasi Masyarakat, 2(2), 44. https://doi.org/10.31850/jdm.v2i2.381

Yuliana, O. Y. (2000). Penggunaan Teknologi Internet Dalam Bisnis. Jurnal Akuntansi Dan Keuangan, 2(1), 36-52. https: //doi.org/10.9744/jak.2.1.pp.36-52

Yuliana, Y., \& Kristiana, V. (2021). Ilomata International Journal of Management ( IJJM ) Ilomata International Journal of Management ( IJJM ). 1, 51-55.

Yurianto, A., \& Bambang Wibowo, K. P. 2020. Pedoman Pencegahan Dan Pengendalian Coronavirus Disease (COVID-19) MI Listiana Azizah, Adistikah Aqmarina

Zainaro, M. A., \& Laila, S. A. (2020). Hubungan Motivasi Dan Sikap Dengan Kepatuhan Perawat Dalam Pelaksanaan Hand Hygiene Di Ruang Rawat Inap Rsud Dr. A. Dadi Tjokrodipo Kota Bandar Lampung. Malahayati Nursing Journal, 2(1), 68-82

https: / / langkatkab.bps.go.id.Kecamatan Bahorok Dalam Angka 2019

https://nasional.kompas.com. 